\title{
Pengaruh Resiko, Kualitas Manajemen, Ukuran dan Likuiditas Bank terhadap Capital Adequacy Ratio Bank- Bank yang Terdaftar di Bursa Efek Indonesia
}

\author{
Farah Margaretha \\ Fakultas Ekonomi Universitas Trisakti \\ Email: farahmargaretha@yahoo.com \\ Diana Setiyaningrum \\ Fakultas Ekonomi Universitas Trisakti
}

\begin{abstract}
Tujuan penelitian ini adalah untuk mengetahui apakah efek risiko, kualitas manajemen, ukuran bank dan likuiditas mempunyai pengaruh terhadap Capital Adequacy Ratio (CAR). Penelitian ini adalah penelitian eksplorasi. Pengambilan sampel menggunakan purposive sampling terhadap bank umum go public yang terdaftar di Bursa Efek Indonesia dan memiliki laporan keuangan yang lengkap selama periode 2003-2008. Metode analisis data yang digunakan dalam penelitian ini adalah Multiple Regression dengan Pooled OLS (Ordinary Least Square) sebagai pengujian common effect dan Fixed-effects Regression. Hasil penelitian ini adalah tingkat pengembalian aset (resiko index), kualitas manajemen, dan likuiditas asset mempunyai pengaruh negatif dan signifikan terhadap CAR. Untuk likuiditas pasiva dilihat dari variabel Equity to Total Liabilities (EQTL) mempunyai pengaruh positif dan signifikan terhadap CAR.
\end{abstract}

Kata kunci: Resiko, kualitas manajemen, ukuran, likuiditas, Capital Adequacy Ratio.

The purposive of this research is to examine the effect of risk, management quality, size and liquidity toward Capital Adequacy Ratio (CAR). This research designed as an explorative research with used purposive sampling method to take the data. Data for this study was collected is publication financial report of banks listed in Indonesian Stock Exchange the period 2003-2008. Statistical analysis by using method of Ordinary Least Square (OLS) and Fixed Effect Method. Result of best examination by using method of Fixed Effect Method. The result of research indicated that index risk (risk of asset turnover), management quality, and asset liquidity have the negative impact toward Capital Adequacy Ratio (CAR). While liquidity of liability have the positive impact toward Capital Adequacy Ratio (CAR).

Keywords: Risk, management quality, size, liquidity, Capital Adequacy Ratio (CAR).

\section{PENDAHULUAN}

Bank adalah lembaga kepercayaan yang berfungsi sebagai lembaga intermediasi, membantu kelancaran sistem pembayaran, dan tidak kalah pentingnya adalah sebagai lembaga yang menjadi sarana dalam pelaksanaan kebijakan pemerintah, yaitu kebijakan moneter. Karena fungsi-fungsinya tersebut, maka keberadaan bank yang sehat, baik secara individu maupun secara keseluruhan sebagai suatu sistem, merupakan prasyarat bagi suatu perekonomian yang sehat. Di Indonesia, sebagaimana diatur dalam undang-undang, yang dimak- sud dengan bank adalah badan usaha yang menghimpun dana dari masyarakat dalam bentuk simpanan dan menyalurkan dana tersebut kembali kepada masyarakat dalam bentuk kredit atau bentuk lain dalam rangka meningkatkan taraf hidup rakyat banyak, disebut dengan fungsi intermediasi. Fungsi intermediasi dapat berjalan dengan baik apabila kedua belah pihak tersebut, yaitu penyimpan dana dan peminjam dana memiliki kepercayaan terhadap bank (Warjiyo 2004).

Mulai tahun 1997 masyarakat kehilangan kepercayaan terhadap lembaga perbankan setelah adanya krisis finansial yang mengakibatkan 
banyak lembaga perbankan di Indonesia mengalami likuidasi, sehingga Bank Indonesia berupaya mengeluarkan kebijakan yang mengatur dan mengawasi lembaga perbankan di Indonesia. Menurut De Bondt dan Prast (2000); ketentuan kecukupan modal bank dapat meningkatkan kepercayaan pemegang saham dan deposan, ketentuan kecukupan modal juga dapat meningkatkan modal bank sehingga menciptakan persaingan yang sehat dalam pasar keuangan global. Bank harus mengatur likuiditas asetnya dalam rangka mencukupi cadangan kewajibannya (reserve requirement) tanpa mengakibatkan biaya yang mahal. Whalen dan Thomson (1988); berpendapat bahwa capital adequacy atau kecukupan modal merupakan komponen penting dalam menilai tingkat kesehatan bank. Ketentuan kecukupan modal harus menetapkan modal bank yang cukup besar sehingga mampu mendukung pengembangan operasi dan kelangsungan hidup bank, menutup resiko yang terjadi dan memberikan insentif bagi pemilik untuk menjaga kepentingannya dalam bank. Setelah bank melakukan kegiatan operasional, maka diberlakukan ketentuan Kewajiban Penyediaan Modal Minimum (KPMM) atau sering disebut Capital Adequacy Ratio (CAR). Menurut Standard Bank for International Settlements, masing-masing negara dapat melakukan penyesuaian dalam menetapkan prinsip-prinsip perhitungan Capital Adequacy Ratio (CAR) dengan menyesuaikan dengan kondisi ekonomi masing-masing negara. Berdasarkan Surat Keputusan Direksi BI No.26/20/Kep/DIR dan SE BI No.26/2/BPPP masing-masing tanggal 29 Mei 1993, telah ditetapkan kewajiban penyediaan modal minimum (CAR). Ketentuan tersebut mengatur bahwa penyediaan modal minimum bank diukur dari persentase tertentu terhadap Aktiva Tertimbang Menurut Resiko (ATMR) sebesar 8\%. Kewajiban Penyediaan Modal Minimum atau Capital Adequacy Ratio tersebut pada dasarnya suatu ukuran modal yang diharapkan dapat menjamin bahwa bank yang beroperasi secara internasional maupun nasional akan beroperasi secara baik. Bank-bank umum di Indonesia wajib menjaga Capital Adequacy Rasio (CAR) sebesar $8 \%$ untuk dapat dikatakan sebagai bank yang sehat. Bank yang memiliki CAR dibawah $8 \%$ atau dibawah ketentuan Bank Indonesia yang berlaku, maka pemilik pengendali diharuskan untuk menambah modal atau kehilangan hak pengendaliannya atas bank dengan kata lain bank memiliki potensi untuk dilikuidasi (Warjiyo,2004). Penelitian Brinkmann dan Horvit (1995); berpendapat bahwa tingginya modal yang dimiliki bank efektif melindungi depositor (sistem asuransi simpanan) terhadap kegagalan bank.
Beberapa penelitian seperti yang dilakukan oleh De Bondt dan Prast (2000), Ghosh et al. (2003), Godlewski (2005) serta Ssenyonga dan Prabowo (2006) yang menguji mengenai rasio permodalan bank membuktikan bahwa modal bank merupakan salah satu faktor yang penting bagi bank dalam mengembangkan usahanya dan menampung resiko kerugian serta penting dalam menghindari likuidasi dan kebangkrutan. Menurut penelitian Ahmad et al. (2008); faktorfaktor penting penentu rasio modal bank memiliki hubungan positif yang kuat antara regulasi modal dan manajemen bank dalam pengambilan resiko. Resiko bank, kualitas manajemen, ukuran bank, serta tingkat likuiditas bank merupakan faktor penting penentu rasio modal bank. Penelitian tersebut menggunakan Non-Performing Loans untuk mengukur resiko bank yang berkaitan dengan resiko pemberian kredit dan resiko nilai index untuk mengukur resiko bank yang berkaitan dengan pengembalian aset. Pendapatan bunga juga menjadi salah satu faktor penting penentuan modal bank. Net Interest Margin (NIM) digunakan sebagai pengukur kualitas manajemen bank yang dilihat dari pendapatan bunga bersih yang mampu diperoleh bank. Ukuran bank (SIZE) dalam hubungannya dengan total aset yang dimiliki dan tingkat likuiditas bank juga merupakan faktor penting dalam menentukan rasio permodalan.

Hasil penelitian Ahmad et al. (2008) menjelaskan bahwa dua variabel resiko yaitu Non-Performing Loans dan resiko index menunjukkan hubungan positif antara rasio kecukupan modal bank dan pengambilan resiko, ini relevan dengan hasil penelitian De Bondt dan Prast (2000); bahwa Capital Adequacy Ratio atau rasio kecukupan modal bank berhubungan positif dengan pengambilan resiko dalam resiko pemberian pinjaman. Penelitian lain yang dilakukan oleh Ssenyonga dan Prabowo (2006) menunjukkan bahwa terdapat hubungan negatif antara Non-Performing Loan dengan Capital Adequacy Ratio, yang berarti bank yang memiliki tingkat aset bermasalah (risky assets) yang lebih tinggi memiliki kecukupan modal yang lebih rendah, sedangkan penelitian Godlewski (2005) menunjukkan bahwa resiko yang diukur dari Non Performing Loans tidak berpengaruh terhadap Capital Adequacy Ratio. Ukuran bank memiliki hubungan yang negatif dengan rasio kecukupan modal pada penelitian Godlewski (2005), sedangkan penelitian Ahmad et al. (2008) menunjukkan ukuran bank tidak berpengaruh signifikan terhadap rasio kecukupan modal. Pada hubungan antara modal dan pendapatan bank menunjukkan bahwa pendapatan memiliki pengaruh pada rasio modal. Net interest 
margin memiliki koefisien negatif, sehingga temuan ini bertentangan dengan pendapat Cebenoyan et al. (1999) bahwa penghasilan tinggi menyediakan akses mudah manajer bank ke ekuitas sehingga meminimalkan resiko. Penelitian Ahmad et al. (2008) dan Pasiouras et al. (2006) menunjukkan likuiditas bank menunjukkan hubungan positif terhadap rasio kecukupan modal.

Penelitian ini bertujuan untuk mengetahui pengaruh resiko, kualitas manajemen, ukuran bank, dan likuiditas bank terhadap Capital Adequacy Ratio bank yang terdaftar di BEI.

\section{RASIO PERMODALAN BANK}

Beberapa penelitian seperti yang dilakukan oleh De Bondt dan Prast (2000), Ghosh et al. (2003), Godlewski (2005) serta Ssenyonga dan Prabowo (2006) yang menguji mengenai rasio permodalan bank membuktikan bahwa modal bank merupakan salah satu faktor yang penting bagi bank dalam mengembangkan usahanya dan menampung resiko kerugian dan kebangkrutan. Menurut penelitian Ahmad et al. (2008); NonPerforming Loans (NPL) digunakan untuk mengukur resiko bank yang berkaitan dengan resiko pemberian kredit dan resiko nilai index untuk mengukur resiko bank yang berkaitan dengan pengembalian aset, yang menunjukkan bahwa resiko memiliki pengaruh signifikan terhadap kecukupan modal bank. Hasil penelitan lainnya juga menunjukkan bahwa pengambilan kredit mempunyai pengaruh pada kecukupan modal. Pendapatan ekonomi juga menjadi salah satu faktor penting penentuan modal bank, dimana pendapatan berkaitan dengan efisiensi dan kemungkinan likuidasi. Net Interest Margin (NIM) digunakan sebagai pengukur kualitas manajemen bank yang dilihat dari pendapatan bunga bersih yang diperoleh bank, hasilnya memperlihatkan bahwa NIM memiliki pengaruh signifikan terhadap rasio kecukupan modal.

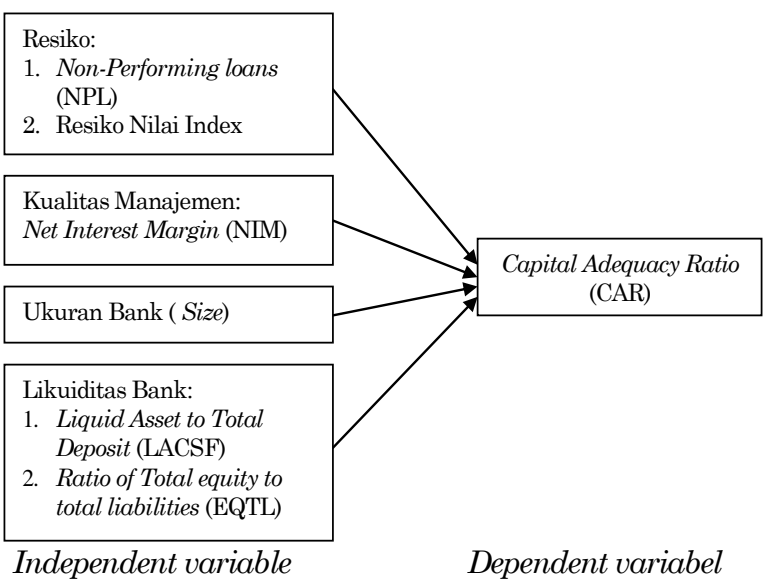

Gambar 1. Skema Kerangka Pemikiran
Ukuran bank (SIZE) dalam hubungannya dengan total aset yang dimiliki dan tingkat likuiditas bank juga merupakan faktor penting dalam mempengaruhi rasio permodalan. Dari hasil penelitian-penelitan tersebut, ingin diketahui pengaruh masing-masing faktor penentu rasio kecukupan modal terhadap Capital Adequacy Ratio (CAR).

\section{METODE PENELITIAN}

Pengambilan sampel dilakukan dengan menggunakan metode purposive sampling karena mengambil sampel yang memiliki kriteria antara lain: merupakan bank umum go public yang terdaftar di Bursa Efek Indonesia dan memiliki laporan keuangan yang lengkap selama periode 2003-2008.

Data yang digunakan dalam penelitian adalah data sekunder. Data diperoleh dalam bentuk yang sudah tertera, dikumpulkan, diolah dan sudah dalam bentuk yang dipublikasikan. Datadata yang digunakan dalam penelitian ini diperoleh dari laporan keuangan bank-bank yang terdaftar di Bursa Efek Indonesia. Semua data keseluruhannya diperoleh dari Indonesian Capital Market Directory (ICMD), Laporan Keuangan Publikasi dari Bank Indonesia dan Bursa Efek Indonesia, www.bi.go.id dan www.idx.co.id.

Untuk lebih selaras pengukuran variable seperti yang tertera pada bagan kerangka pemikiran dapat dilihat pada Table 1.

Metode analisis data yang akan digunakan dalam penelitian ini adalah Multiple Regression dengan Pooled OLS (Ordinary Least Square) sebagai pengujian common effect dan Fixed-effects Regression sebagai pengujian individual effect, Chow test digunakan sebagai analisa penentu model yang terbaik untuk digunakan. Pengujian statistik ini diolah dengan menggunakan software eviews 4,1. Metode ini menggunakan data panel dimana di dalam metode ini data cross sectional di kombinasikan dengan data time series sehingga menghasilkan estimasi yang konsisten untuk menguji pengaruh variabel independent (NonPerforming Loans, Resiko Index, Net Interest Margin, Size, Liquid Asset to Total Deposit dan Equity to Total Liabilities) terhadap variabel dependen (CAR) yang masing-masing memiliki skala rasio.

Sehingga model yang ditetapkan untuk dipakai adalah sebagai berikut:

$\mathrm{Y}=£_{0}+B_{1} \mathrm{X}_{1}+\mathrm{B}_{2} \mathrm{X}_{2}+\mathrm{B}_{3} \mathrm{X}_{3}+\mathrm{B}_{4} \mathrm{X}_{4}+\mathrm{B}_{5} \mathrm{X}_{5}+\mathrm{B}_{6} \mathrm{X}_{6}+\varepsilon i$

Dimana:

$\mathrm{Y}=$ Capital Adequacy Ratio $(\mathrm{CAR})$ 
$£_{0}=$ Konstanta

$\mathrm{X}_{1}=$ Non-Performing Loans

$\mathrm{X}_{2}=$ Resiko Nilai Index

$\mathrm{X}_{3}=$ Net Interest Margin

$\mathrm{X}_{4}=$ Size

$\mathrm{X}_{5}=$ Liquid Asset to Total Deposit (LACSF)

$\mathrm{X}_{6}=$ Equity to Total Liabilities (EQTL)

$\varepsilon i=$ error

Tabel 1. Indikator Variabel

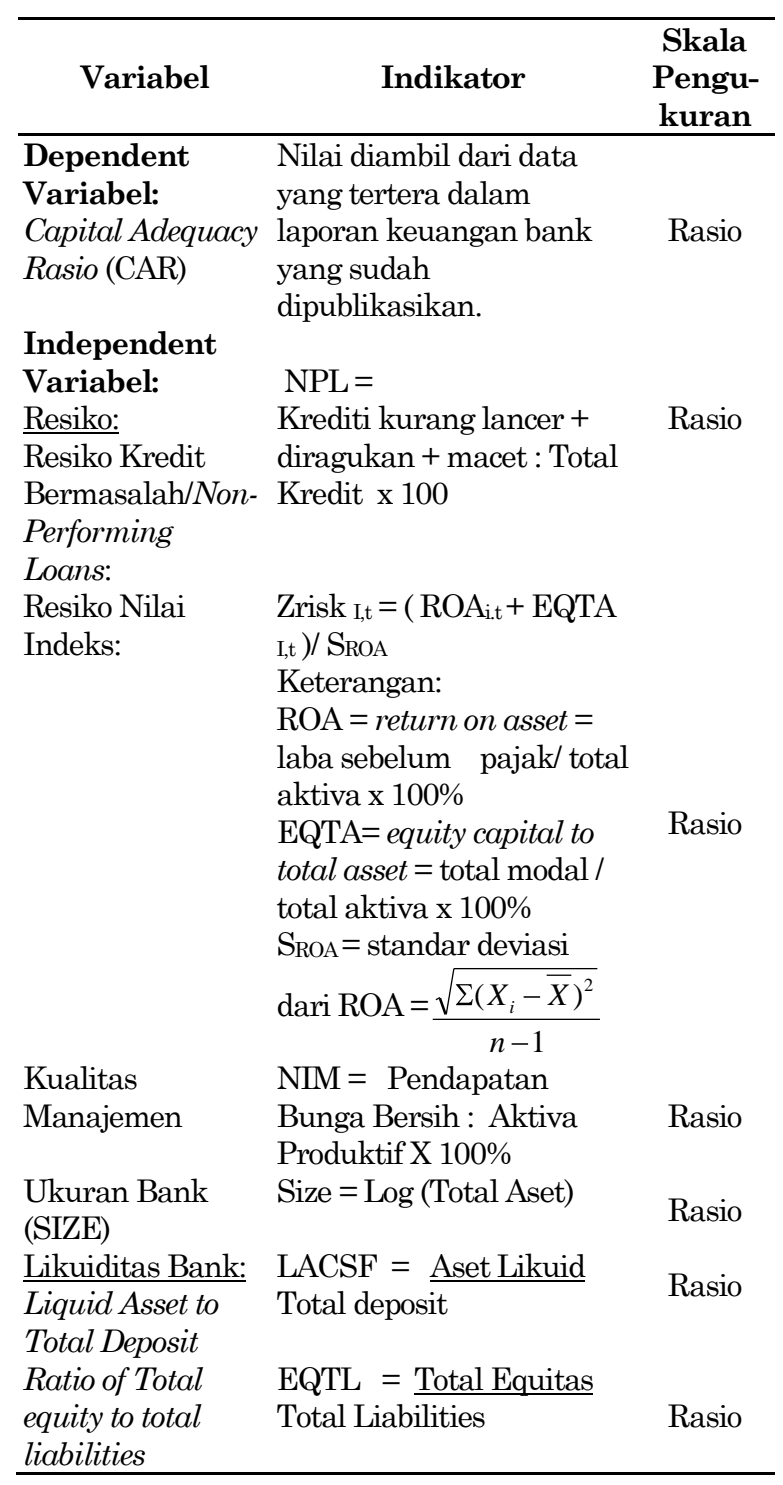

\section{PEMBAHASAN}

Data yang digunakan adalah 21 bank yang memenuhi kriteria untuk dijadikan sampel. Bankbank tersebut telah melakukan kegiatan operasionalnya selama lebih dari 6 tahun dan memiliki laporan keuangan yang lengkap dengan tahun penelitian 2003-2008 lihat Tabel 2.
Tabel 2. Daftar bank go public yang terdaftar di Bursa Efek Indonesia

No Kode Nama Bank $\begin{gathered}\text { Tanggal } \\ \text { Berdiri }\end{gathered} \begin{gathered}\text { Tanggal } \\ \text { Listing }\end{gathered}$ Status

1 AGRO Agroniaga 27-03-1989 08-08-2003PMDN Tbk Bank Artha

2 INPC $\begin{aligned} & \text { Graha } \\ & \text { Internasional 09-07-1973 23-08-1990PMDN }\end{aligned}$ Tbk

3 BBCA $\begin{aligned} & \text { Bank Central 10-10-1955 31-05-2000PMDN } \\ & \text { Asia Tbk }\end{aligned}$ Asia Tbk

4 BNGA $\begin{aligned} & \text { Bank CIMB Niaga Tbk 11-01-1901 29-11-1989PMDN } \\ & \text { Bank }\end{aligned}$ Bank

5 BDMNDanamon 11-01-1901 12-06-1989BUMN Indonesia Tbk Bank

6 BEKS Eksekutif 11-09-1992 13-07-2001PMDN Tbk Bank ICB

7 BABP Bumiputera 31-07-1989 14-07-2002PMDN Tbk Bank

8 BNII Internasional 15-05-1959 21-11-2002PMDN Indonesia Tbk

9 BKSW $\begin{aligned} & \text { Bank } \\ & \text { Kesawan Tbk 28-04-1913 21-11-2002PMDN }\end{aligned}$

10 BMRI Bank Mandiri 10-02-1998 14-07-2003BUMN Bank

11 MAYA $\begin{gathered}\text { Mayapada } \\ \text { Internasional }\end{gathered}$ 10-01-1990 29-08-1997PMDN Tbk

12 MEGA $\underset{\text { Tbk }}{\text { Bank Mega 15-04-1965 07-04-2000PMDN }}$ Bank Negara

13 BBNI Indonesia 11-01-1901 25-11-1996BUMN (Persero) Tbk Bank

14 BBNP Nusantara 18-01-1792 10-01-2001PMDN Tbk

15 NISP $\begin{aligned} & \text { Bank OCBC 11-01-1901 25-11-1996PMDN } \\ & \text { NISP Tbk }\end{aligned}$ NISP Tbk

16 BNLI $\begin{aligned} & \text { Bank } \\ & \text { Permata Tbk 17-12-1954 15-01-1990PMDN }\end{aligned}$ Bank Rakyat

17 BBRI Indonesia 16-12-1895 10-10-2003BUMN (Persero) Tbk

18 BSDW ${ }_{\text {Tbk }}^{\text {Bank Swadesi }}$ 28-09-1968 01-05-2002PMDN

19 BBNA $\begin{aligned} & \text { Bank UOB } \\ & \text { Buana Tbk }\end{aligned}$ 31-08-1956 28-07-2000BUMN Bank Victoria

20 BVIC Internasional 28-10-1992 30-06-1999PMDN Tbk PAN

21 PNBN Indonesia Bank Tbk 17-08-1971 29-12-1982PMDN Sumber: Indonesian Capital Market Directory (ICMD) 
Statistik deskriptif adalah bagian dari ilmu statistik yang hanya mengolah, menyajikan data tanpa mengambil keputusan untuk populasi. Dengan kata lain hanya melihat gambaran secara umum dari data yang didapatkan. Statistik diskriptif bertujuan untuk memberikan gambaran atau deskripsi data dengan menggunakan pendekatan statistik. Statistik deskriptif menjelaskan tentang karakteristik data yang digunakan dalam penelitian dilihat dari nilai minimum, maksimum, mean (rata-rata) dan standar deviasi.

Berikut ini merupakan statistik deskriptif dari indikator variabel yang digunakan lihat Tabel 3.

Tabel 3. Statistik Deskriptif

\begin{tabular}{|c|c|c|c|c|c|}
\hline & $\mathbf{N}$ & $\begin{array}{l}\text { Mini- } \\
\text { mum }\end{array}$ & $\begin{array}{l}\text { Maxi- } \\
\text { mum }\end{array}$ & Mean & $\begin{array}{c}\text { Std. } \\
\text { Deviation }\end{array}$ \\
\hline CAR & 108 & 9.36 & 30.87 & 17.1787 & 5.18102 \\
\hline NPL & 108 & .12 & 10.47 & 3.6884 & 2.30058 \\
\hline ZRISK & 108 & .45 & 86.98 & 25.2763 & 17.19111 \\
\hline NIM & 108 & 2.11 & 9.83 & 4.8759 & 1.38785 \\
\hline SIZE & 108 & 5.80 & 9.33 & 7.2137 & .76410 \\
\hline LACSF & 108 & .00 & .23 & .1027 & .03351 \\
\hline EQTL & 108 & .05 & .24 & .1071 & .03434 \\
\hline $\begin{array}{l}\text { Valid N } \\
\text { (listwise }\end{array}$ & 108 & & & & \\
\hline
\end{tabular}

Sumber: data diolah SPSS 11,5

Pengujian secara parsial digunakan untuk melihat signifikansi dari pengaruh masing-masing variabel independen terhadap variabel dependen secara keseluruhan (common effect) dengan mengasumsikan variabel lain adalah konstan.

Tabel 4. Hasil Uji Ordinary Least Square

\begin{tabular}{lccc}
\hline Variabel & Koefisien & Signifikansi & Kesimpulan \\
\hline Constanta & 1,927 & 0,609 & Tidak Signifikan \\
NPL & $-0,362$ & 0,010 & Signifikan \\
ZRISK & $-0,015$ & 0,448 & Tidak Signifikan \\
NIM & $-1,079$ & 0,000 & Signifikan \\
SIZE & 1,327 & 0,004 & Signifikan \\
LACSF & $-1,605$ & 0,868 & Tidak Signifikan \\
EQTL & 119,764 & 0,000 & Signifikan \\
\hline
\end{tabular}

Sumber: data diolah Eviews 4,1

Persamaan regresi yang terbentuk adalah sebagai berikut:

$$
\begin{aligned}
\mathrm{CAR}= & 1,927-0,362 \mathrm{NPL}-0,015 \mathrm{ZRISK}-1,079 \\
& \mathrm{NIM}+1,327 \mathrm{SIZE}-1,605 \mathrm{LACSF}+ \\
& 119,764 \mathrm{EQTL}+\varepsilon
\end{aligned}
$$

Diketahui koefisien konstanta sebesar 1,927. Hal ini berarti jika variable independent bernilai konstan maka CAR akan meningkat sebesar 1,927. Signifikansi yang didapat sebesar 0,609 > 0,05. Maka konstanta tidak berpengaruh terhadap CAR. Dari pengujian regresi berganda dapat dilihat bahwa NPL mempunyai koefisien sebesar 0,362 terhadap CAR. Nilai signifikansi yang didapat sebesar 0,010 lebih kecil dari 0,05. Maka yang berarti bahwa terdapat pengaruh antara NPL terhadap CAR. Variabel ZRISK mempunyai koefisien sebesar -0,015 terhadap CAR. Nilai signifikansi yang didapat sebesar 0,448 lebih besar dari 0,05 yang berarti tidak terdapat pengaruh antara ZRISK terhadap CAR. Variabel NIM mempunyai koefisien sebesar -1,079 terhadap CAR. Nilai signifikansi yang didapat sebesar 0,000 lebih kecil dari 0,05 yang berarti bahwa tidak terdapat pengaruh antara NIM terhadap CAR. Variabel SIZE mempunyai koefisien sebesar 1,327 terhadap CAR dengan nilai signifikansi yang didapat sebesar 0,004 lebih kecil dari 0,05 yang berarti bahwa variabel SIZE berpengaruh terhadap CAR. Variabel LACSF mempunyai koefisien sebesar 1,605 terhadap CAR. Nilai signifikansi yang didapat sebesar 0,868 lebih besar dari 0,05 yang berarti bahwa variabel LACSF tidak memiliki pengaruh terhadap CAR. Variabel EQTL mempunyai koefisien sebesar 119,764 terhadap CAR. Nilai signifikansi yang didapat sebesar 0,000 lebih kecil dari 0,05 yang berarti bahwa EQTL berpengaruh terhadap CAR.

Pengujian Fixed Effect merupakan salah satu pengujian individual effect. Pengujian regresi fixed effect adalah bahwa satu objek, memiliki konstanta yang tetap besarnya untuk berbagai periode waktu. Demikian juga dengan koefisien regresinya, tetap besarnya dari waktu ke waktu/ time invariant (Winarno 2007).

Dengan menggunakan metode fixed effect didapat hasil seperti Tabel 5.

\section{Tabel 5. Hasil Uji t Fixed Effect}

\begin{tabular}{cccc}
\hline Variabel & Koefisien & Signifikansi & Kesimpulan \\
NPL & $-0,160$ & 0,294 & Tidak Signifikan \\
ZRISK & 0,185 & 0,018 & Signifikan \\
NIM & $-0,859$ & 0,010 & Signifikan \\
SIZE & $-0,270$ & 0,536 & Tidak Signifikan \\
LACSF & $-19,591$ & 0,018 & Signifikan \\
$E Q T L$ & 77,895 & 0,000 & Signifikan \\
\hline
\end{tabular}

Sumber: data diolah Eviews 4,1

Dari pengujian regresi berganda dengan metode fixed effect dapat dilihat bahwa NPL mempunyai koefisien negatif sebesar -0,160. Nilai signifikansi yang didapat sebesar 0,294 lebih besar dari 0,05. Hal ini berarti tidak terdapat pengaruh antara NPL terhadap CAR. Variabel ZRISK mempunyai oefisien positif sebesar 0,185. Nilai signifikansi yang didapat sebesar 0,018 lebih kecil dari 0,05 yang berarti terdapat engaruh antara ZRISK terhadap CAR. Variabel NIM mempunyai koefisien negatif sebesar -0,859 dengan nilai signify- 
kansi sebesar 0,010 yang lebih kecil dari 0,05. Hal ini berarti bahwa variabel NIM mempunyai pengaruh negatif terhadap CAR. Variabel SIZE mempunyai koefisien negatif sebesar 0,270. Nilai signifikansi yang didapat sebesar 0,536 lebih besar dari 0,05 yang berarti bahwa SIZE tidak berpengaruh terhadap CAR. Variabel LACSF mempunyai koefisien negatif sebesar -19,591. Nilai signifikansi yang didapat sebesar 0,018 lebih kecil dari 0,05 yang berarti bahwa terdapat pengaruh negatif antara LACSF terhadap CAR. Variabel EQTL mempunyai koefisien positif sebesar 77,895. Nilai signifikansi yang didapat sebesar 0,000 lebih kecil dari 0,05, yang berarti bahwa terdapat pengaruh positif antara EQTL terhadap CAR.

Dalam penelitian ini menggunakan dua pendekatan dalam mengestimasi data panel, yaitu Ordinary Least Square (OLS) yang merupakan pengujian secara parsial (pengaruh secara keseluruhan) dan Fixed Effect Model yang merupakan salah satu pengujian secara individu (individual effect) oleh karena itu kita perlu melakukan pengujian untuk menentukan mana diantara kedua pendekatan tersebut yang paling sesuai dan paling baik digunakan sebagai penentu keputusan.

Untuk menguji model terbaik antara Ordinary Least Square (OLS) dan Fixed Effect kita bisa menggunakan Chow Test untuk mendapatkan nilai F-hitung.

Hipotesis:

$\mathrm{H}_{0}: \mathrm{a}_{1}=\mathrm{a}_{2}=\mathrm{a}_{3}=\ldots .=\mathrm{a}_{\mathrm{i}}$, Ordinary Least Square (Restricted)

$\mathrm{H}_{\mathrm{a}}: \mathrm{\alpha}_{1} \neq \mathrm{\alpha}_{2} \neq \mathrm{\alpha}_{3} \neq \ldots . \ldots \mathrm{\alpha}_{\mathrm{i}}$, Fixed Effect (Unrestricted) dimana Chow Test dirumuskan sebagai berikut:

$$
C H O W=\frac{(R R S S-U R S S) /(N-1)}{U R S S /(N T-N-K)}
$$

Keterangan:

$\begin{aligned} \text { RRSS = } & \text { Restricted Residual Sum Square (Meru- } \\ & \text { pakan Sum of Square Residual yang } \\ & \text { diperoleh dari estimasi data panel } \\ & \text { dengan metode ordinary least square) } \\ \text { URSS = } & \text { Unrestricted Residual Sum Square } \\ & \text { (Merupakan Sum of Square Residul } \\ & \text { yang diperoleh dari estimasi data panel } \\ & \text { dengan metode fixed effect) } \\ = & \text { Jumlah data cross section } \\ \mathrm{N}= & \text { Jumlah data time series } \\ \mathrm{T} \quad & \text { Jumlah variabel penjelas } \\ \mathrm{K} \quad & \end{aligned}$

Untuk pengambilan keputusan apakah $\mathrm{H}_{0}$ atau $\mathrm{H}_{\mathrm{a}}$ yang diterima maka bandingkan hasil $F$ statistic dengan F-table ( $\mathrm{F}$ alfa, n-k, obs-var). Jika
$F$-stat lebih besar daripada $F$-table maka $\mathrm{H}_{0}$ ditolak sehingga $\mathrm{H}_{\mathrm{a}}$ diterima yang artinya model yang digunakan adalah Fixed Effect dan sebaliknya.

Perhitungan Chow Test mendapatkan hasil sebagai berikut:

$$
\begin{aligned}
\text { Chow Test } & =\frac{(1061,191-434,1223) /(21-1)}{434,1223 /(108-21-6)} \\
& =\frac{31,353435}{5,359534568}=5,85
\end{aligned}
$$

Dari hasil perhitungan chow test diperoleh hasil $F$ statistic sebesar 5,85 lebih besar dari $F$ table 1,75, hasil ini berarti bahwa $\mathrm{H}_{0}$ ditolak dan $\mathrm{H}_{\mathrm{a}}$ diterima yaitu model yang lebih baik digunakan adalah Fixed Effect Model.

Dasar dilakukannya penelitian ini adalah untuk mengetahui faktor-faktor yang mempengaruhi Capital Adequacy Ratio (CAR), antara lain pengaruh resiko yang diukur dari resiko kredit macet (Non-Performing Loans) dan resiko nilai index (ZRISK), pengaruh kualitas manajemen/Net Interest Margin (NIM), pengaruh ukuran bank (SIZE) dan pengaruh likuiditas yang dilihat dari Liquid Asset to Total Deposit (LACSF) dan Equity to Total Liabilities (EQTL) terhadap Capital Adequacy Ratio (CAR). Non-Performing Loans (NPL) merupakan varibel resiko kredit bermasalah, dimana tingginya NPL menandakan bahwa resiko kegagalan pembayaran kredit juga tinggi. Besarnya resiko kredit bermasalah/ NonPerforming Loans (NPL) akan menyebabkan bank harus membentuk cadangan penghapusan kredit (the provision for loan losses), pembentukan cadangan penghapusan kredit ini akan menyebabkan berkurangnya penghasilan yang dapat dijadikan tambahan modal, sehingga kecukupan akan kebutuhan modal akan berkurang (Rose dan Hudgins 2009). Resiko Nilai Indeks (ZRISK) merupakan resiko dari tingkat pengembalian aset (standar deviasi dari Return on Asset) sehingga apabila resiko index tinggi yang berarti resiko tingkat pengembalian aset besar, sehingga mengakibatkan produktifitas aset dalam memperoleh keuntungan menurun, sehingga turut menurunkan kecukupan modal (CAR) (Hasibuan 2008). Kualitas manajemen yang dilihat dari Net Interest Margin (NIM) menandakan bahwa semakin tinggi kualitas manajemen dalam menghasilkan keuntungan bunga, berarti bank lebih cenderung menempatkan dananya pada aktiva-aktiva yang produktif. Pada aktiva-aktiva produktif terkandung resiko yang besar, sehingga semakin besar dana pada aktiva produktif maka aktiva tertimbang menurut resiko bank akan semakin besar. 
Semakin besar aktiva tertimbang menurut resiko maka rasio kecukupan modal akan menurun (Taswan 2006). Variabel SIZE menggambarkan ukuran perusahaan dilihat dari aset yang dimiliki, sehingga semakin besar aset yang dimiliki maka semakin besar modal yang dapat dipenuhi (Ssenyonga and Prabowo,2006). Hasil ini relevan dengan penelitian Cebenoyan et.al (1999), Pasiouras et al. (2006) dan hasil penelitian Ssenyonga and Prabowo (2006), menunjukkan bahwa ukuran bank yang dilihat dari besarnya aset memiliki hubungan positif terhadap modal bank. Aset yang lebih besar akan mendorong likuiditas bank sehingga dapat meningkatkan modal mereka lebih besar juga. Penelitian lain yang dilakukan oleh Keeton (1989) juga menunjukkan bahwa bank yang memiliki kelebihan (surplus) modal lebih tinggi dari kebutuhan modal, lebih berhasil dalam memenuhi peraturan kecukupan modal minimum, sedangkan bank yang memiliki modal lebih rendah dari kebutuhan modalnya sendiri, cenderung mengalami kegagalan dalam memenuhi peraturan kecukupan modal minimum. Likuiditas yang diukur dari variabel Liquid Asset to Total Deposit (LACSF) menggambarkan likuiditas yang dilihat dari jumlah aset likuid yang dimiliki terhadap jumlah kewajiban yang harus segera dipenuhi. Semakin tinggi likuiditas asset yang dimiliki bank dalam arti bahwa bank menaruh dana lebih besar pada kas, giro pada BI, atau giro pada bank lain yang merupakan aktiva yang tidak produktif (tidak menghasilkan keuntungan), sehingga loanable funds (dana yang dapat digunakan sebagai pinjaman) yang dapat menghasilkan keuntungan akan berkurang porsinya. Dana yang mengendap pada aset likuid tersebut merupakan dana yang berasal dari penghimpunan dana masyarakat yang didalamnya terdapat unsur biaya bunga. Sehingga semakin besar dana mengendap pada aset likuid berarti biaya dana yang ditanggung bank semakin besar tanpa diimbangi dengan pendapatan, yang akhirnya akan mengakibatkan kerugian dan berkurangnya modal (Hasibuan 2008). Sedangkan variabel Equity to Total Liabilities (EQTL) yang menunjukkan likuiditas bank yang dilihat dari sisi pasiva yaitu dari total ekuitas yang dimiliki terhadap jumlah kewajiban yang harus dipenuhi. Likuiditas pasiva yang tinggi menandakan bahwa bank memiliki dana lebih besar pada sisi pasiva yang berasal dari dana pihak ketiga yang kemudian digunakan sebagai modal tambahan. Penambahan modal mengakibatkan rasio kecukupan modal/Capital Adequacy Ratio meningkat (Taswan 2006).

Hasil pengujian Chow Test yang dilakukan menunjukkan bahwa metode analisis yang paling baik digunakan dalam pengujian ini adalah metode Fixed Effect, dengan hasil sebagai berikut:

Tabel 6. Hasil Fixed Effect

\begin{tabular}{lccc}
\hline Variabel & Koefisien & Signifikan & Kesimpulan \\
\hline NPL & $-0,160$ & 0,294 & Tidak Signifikan \\
ZRISK & 0,185 & 0,018 & Signifikan \\
NIM & $-0,859$ & 0,010 & Signifikan \\
SIZE & $-0,270$ & 0,536 & Tidak Signifikan \\
LACSF & $-19,591$ & 0,018 & Signifikan \\
EQTL & 77,895 & 0,000 & Signifikan \\
\hline
\end{tabular}

Keterangan: signifikan pada a 0,05

Penggunaan metode Fixed Effect merupakan metode pengujian yang terbaik dalam penelitian ini, metode ini memperlihatkan hasil bahwa variabel resiko yang diukur dari tingkat resiko kredit bermasalah (Non-Performing Loans)tidak mempunyai pengaruh terhadap Capital Adequacy Ratio (CAR), hasil ini relevan dengan penelitian yang dilakukan oleh Godlewski (2005) yang menggunakan Non-Performing Loans sebagai pengukuran resiko dalam pengaruhnya terhadap modal. Hal ini dikarenakan adanya kebijakan pemerintah yang berusaha mencegah resiko kredit macet ini, seperti memberikan batas maksimum pemberian kredit (BMPK), menetapkan NonPerforming Loans maksimal 5\%, pembentukan cadangan penyisihan aktiva produktif, dan penghapusan kredit, dimana penghapusan kredit ini hanya sebagai penghapusbukuan sehingga upaya penagihan tetap dilakukan (Hasibuan 2008; Taswan 2006). Campur tangan pemerintah juga turut berperan dalam penyelamatan kredit bermasalah, seperti dengan memberi bantuan injeksi kredit atau pengambil alihan resiko kredit macet ini dengan penyerahan kewajiban kepada BUPN/Badan Urusan Piutang Negara (Dendawijaya 2005).

Variabel pengambilan resiko yang lain diukur dari resiko index yaitu yang menggambarkan resiko tingkat pengembalian aset. Hasil metode Fixed Effect menunjukkan bahwa koefisien dari resiko index adalah positif dan signifikan. Tanda positif dalam resiko index menandakan bahwa resiko pengembalian aset tinggi (Ahmad et al. 2008). Resiko index yang tinggi berarti bahwa produktifitas aset tersebut endah. Produktifitas aset yang rendah menurunkan profitabilitas yang akhirnya berpengaruh dalam menurunnya pemenuhan kecukupan modal (Hasibuan 2008).

Kualitas manajemen yang diukur dari Net Interest Margin (NIM) menunjukkan pengaruh negatif dan signifikan terhadap Capital Adequacy Ratio (CAR). Hasil iniberarti bahwa kualitas manajemen yang dilihat dari kemampuan bank dalam menghasilkan keuntungan bunga bersih 
menandakan bahwa semakin tinggi kualitas manajemen dalam menghasilkan keuntungan bunga, berarti bank lebih cenderung menempatkan dananya pada aktiva-aktiva yang produktif. Pada aktiva-aktiva produktif terkandung resiko yang besar, sehingga semakin besar dana pada aktiva produktif akan aktiva tertimbang menurut resiko bank akan semakin besar. Semakin besar aktiva tertimbang menurut resiko maka rasio kecukupan modal akan menurun (Taswan 2006).

Hasil penelitian ini relevan dengan penelitian Ahmad et al. (2008), bahwa kualitas manajemen yang dilihat dari kemampuan menghasilkan laba menunjukkan bahwa tingginya penghasilan yang diperoleh dari keuntungan bunga bersih (Net Interest Margin) menyebabkan manajemen bank mengurangi modal sehingga memberikan resiko kegagalan lebih rendah.

Variabel ukuran bank (Size) yang diukur dari jumlah aset yang dimiliki menandakan bahwa ukuran bank tidak mempunyai pengaruh dalam pemenuhan kecukupan modal minimum atau Capital Adequacy Ratio (CAR). Hasil penelitian ini relevan dengan penelitian yang dilakukan oleh Ahmad et al. (2008); bahwa ukuran bank dilihat dari jumlah aset yang dimiliki tidak mempunyai pengaruh bagi kecukupan modal.

Hasil metode fixed effect menunjukkan bahwa variabel Liquid Asset to Total Deposit (LACSF) yang menggambarkan likuiditas dari aset likuid yang dimiliki terhadap jumlah kewajiban yang harus segera dipenuhi mempunyai pengaruh negatif dan signifikan terhadap kecukupan modal. Hal ini berarti bahwa semakin tinggi likuiditas aset yang dimiliki bank dalam arti bahwa bank menaruh dana lebih besar pada kas, giro pada BI, atau giro pada bank lain yang merupakan hal-hal yang tidak produktif (tidak menghasilkan keuntungan), sehingga loanable funds (dana yang dapat digunakan sebagai pinjaman) yang dapat menghasilkan keuntungan akan berkurang porsinya. Dana yang mengendap pada aset likuid tersebut merupakan dana yang berasal dari penghimpunan dana masyarakat yang didalamnya terdapat unsur biaya bunga. Sehingga semakin besar dana mengendap pada aset likuid berarti biaya dana yang ditanggung bank semakin besar tanpa diimbangi dengan pendapatan, yang akhirnya akan mengakibatkan kerugian dan berkurangnya modal (Hasibuan 2008).

Variabel likuiditas yang diukur dari Equity to Total Liabilities (EQTL) menunjukkan likuiditas bank yang dilihat dari sisi pasiva yaitu dari total ekuitas yang dimiliki terhadap jumlah kewajiban yang harus dipenuhi. Hasil Fixed Effect menunjukkan bahwa variabel Equity to Total Liabilities (EQTL) mempunyai pengaruh positif dan signifikan terhadap Capital Adequacy Ratio (CAR). Hasil ini berarti bahwa likuiditas bank mendorong kecukupan modal bank, relevan dengan hasil penelitian Ahmad et al. (2008); Ssenyoga dan Prabowo (2006) dan Pasiouras et al. (2006). Likuiditas pasiva yang tinggi menandakan bahwa bank memiliki dana lebih besar pada sisi pasiva yang berasal dari dana pihak ketiga yang kemudian digunakan sebagai modal tambahan. Penambahan modal mengakibatkan rasio kecukupan modal/Capital Adequacy Ratio meningkat (Taswan 2006).

\section{KESIMPULAN}

Berdasarkan hasil pengujian maka dapat ditarik kesimpulan sebagai berikut: hasil pengujian dengan metode Ordinary Least Square (OLS) menemukan bahwa: 1) resiko dari kredit bermasalah (Non-Performing Loans) mempunyai pengaruh negatif dan signifikan terhadap CAR, 2) resiko dilihat dari tingkat pengembalian aset (resiko index) tidak mempunyai pengaruh terhadap CAR, 3) kualitas manajemen dilihat dari kemampuan menghasilkan laba/Net Interest Margin (NIM) mempunyai pengaruh negatif dan signifikan terhadap CAR, ukuran bank (SIZE) mempunyai pengaruh positif dan signifikan terhadap CAR, 4) likuiditas aset dilihat dari Liquid Asset to Total Deposit (LACF) tidak mempunyai pengaruh terhaap CAR dan 5) likuiditas pasiva dilihat dari variabel Equity to Total Liabilities (EQTL) mempunyai pengaruh positif dan signifikan terhadap CAR.

Hasil pengujian Chow Test menunjukkan bahwa metode Fixed Effect lebih sesuai dan metode yang terbaik untuk digunakan dalam penelitian ini. Hasil pengujian metode Fixed Effect menemukan bahwa: 1) Resiko dari kredit bermasalah (Non-Performing Loans) tidak mempunyai pengaruh signifikan terhadap CAR, 2) resiko dari tingkat pengembalian aset/ resiko indeks (ZRISK) mempunyai pengaruh negatif dan signifikan terhadap CAR, 3) kualitas manajemen dilihat dari kemampuan menghasilkan laba/Net Interest Margin (NIM) mempunyai pengaruh negatif dan signifikan terhadap CAR, 4) ukuran bank (SIZE) tidak mempunyai pengaruh signifikan terhadap CAR, 5) likuiditas aset dilihat dari Liquid Asset to Total Deposit (LACSF) mempunyai pengaruh negatif dan signifikan terhadap CAR, 6) likuiditas pasiva dilihat dari Equity to Total Liabilities (EQTL) mempunyai pengaruh positif dan signifikan terhadap CAR.

Berdasarkan kesimpulan diatas maka perlu adanya campur tangan pemerintah dalam menilai tingkat kesehatan bank. Terbukti dalam kasus bank-bank milik Pemerintah (BUMN) seperti 
Bank Mandiri, Bank Negara Indonesia, dan Bank Rakyat Indonesia yang memiliki tingkat resiko kredit bermasalah yang tinggi namun dinilai sehat karena Capital Adequacy Ratio-nya juga tinggi. Hal ini dapat menyebabkan persaingan unfair pada industri perbankan di Indonesia, sehingga investor yang ingin menanamkan dananya pada bank-bank BUMN sebaiknya melihat faktor-faktor penilai tingkat kesehatan bank yang lain, seperti kualitas aktiva produktif, kualitas dari sistem dan prosedur operasional bank dan tingkat rentabilitas bank.

\section{DAFTAR PUSTAKA}

Ahmad, R, Ariff, M. \& Skully, M.J. 2008. "The Determinant of Bank Capital Ratios in a Developing Economy", Asia-Pasific Financial Markets, 15:255-272.

Brinkmann, E.J, and Horvitz, P.M. 1995. "Riskbased Capital Standards and the Credit Crunch", Journal of Money, Credit and Banking, 27(3):848.

Cebenoyan, A.S.; Cooperman, E.S. \& Register, C.A. 1999. Ownership Structure, Charter Value, and Risk-Taking Behaviour for Thrifts, Financial Management, 28(1):43-60.

De Bondt, G.J, and Prast.H.M. 2000. "Bank Capital Ratios in the 1990s: Cross-country evidence", Banca Nazionale del Lavoro Quarterly Riview, 53(212):71.

Dendawijaya, L. 2005. Manajemen Perbankan. Edisi kedua, Bogor: Penerbit Ghalia Indonesia.

Ghosh, S.; Nachane, D.M.; Narain, A.; Sahoo, S. 2003. Capital Requirements and Bank Behaviour: An Emperical Analysis of Indian Public Sector Banks, Journal of International Development, 15:145-156.

Ghozali, I. 2002. Aplikasi Analisis Multivariate dengan Program SPSS, Semarang: Badan Penerbit UNDIP.
Godlewski, C.J. 2005. Bank Capital and Credit Risk Taking in Emerging Market Economies, Journal of Banking Regulation, 6(2):128.

Hasibuan, M.S.P. 2008. Dasar-dasar Perbankan. Cetakan ketujuh, Jakarta: Penerbit Bumi Aksara.

Keeton, R.W. 1989. The New Risk-Based Capital Plan for Commercial Banks, Economic Review-Federal Reserve Bank of Kansas City, 74(10):40.

Pasiouras, F.; Gaganis, C.\& Zopounidis, C. 2006. The Impact of Bank Regulations, Supervision, Market Structure, and Bank Characteristics on Individual Bank Rating: A Cross Country Analysis. Review Quarterly Financial Accounting. 27:403-438.

Rose. P.S. and Hudgins. S.C. 2009. Bank Management \& Financial Services (8th ed.), New York: McGraw-Hill.

Ssenyonga, M. and Prabowo, D. 2006. Bank Risk Level and Bank Capital: The Case of The Indonesian Banking Sector, Jurnal Ekonomi dan Bisnis Indonesia, 21(2):122-137.

Taswan. 2006. Manajemen Perbankan: Konsep Teknik dan Aplikasi. Edisi 1, Yogyakarta: Penerbit UPP STIM YKPN Yogyakarta.

Warjiyo, P. 2004. Bank Indonesia Bank Sentral Republik Indonesia: Sebuah Pengantar. Jakarta: Pusat Pendidikan dan Studi Kebanksentralan (PPSK).

Whalen, G.and Thomson, J.B. 1988. "Using Financial Data to Identify Changes in Bank Condition", Economic Review- Federal Reserve Bank of Cleveland, 24(2):17.

Winarno, W.W. 2007. Analisis Ekonometrika dan Statistika Dengan Eviews. Edisi1, Yogyakarta: Penerbit UPP STIM YKPN Yogyakarta. 